\title{
Russian Arctic: Environmental Challenges and Legal Responses
}

\author{
Irina O. Krasnova and Valery N. Vlasenko* \\ Russian State University of Justice \\ 69 Novocheremushkinskaya Str., Moscow, 117418, Russia
}

Received 02.04.2018, received in revised form 27.05.2018, accepted 04.06.2018

The article analyzes the environmental legislative acts as applied to the unique Arctic ecosystem. The authors make a conclusion that the legislation may be assessed as fragmentary with certain gaps and deficiencies, including those connected with the response to the global climate change. It is substantiated that the integrity of the Arctic ecosystem, its fragile nature and a perspective of a growing economic use of its natural resources make it reasonable to prepare and adopt a comprehensive legislative act on environmental protection in the Arctic Zone of the RF that would cover the issues of emission limitations, best available techniques, response actions to oil spills, biodiversity conservation, removal of stocked environmental damage, comprehensive management of the coastal zone, and adaptation measures to climate change.

Keywords: strategy for the Arctic Zone development, stocked environmental damage, emission limitations, oil spills responses, adaptation to climate change, ecological development.

DOI: 10.17516/1997-1370-0282.

Research area: law.

The Arctic region is a northern polar region of the Earth occupying an area down from the Arctic Pole and comprising the Arctic Ocean, northern parts down to the Arctic Circle of the surface territories of eight Arctic states (Canada, Denmark (via Greenland), Russia, Norway, Sweden, Finland, Iceland, and the USA) and the extreme northern parts of the Pacific and Atlantic Oceans (Arktika; Kolodkin, 2007). It consists of a vast ice-covered ocean surrounded by permafrost. The Arctic is known for its rich reserves of natural resources - oil, gas, minerals, fresh water, fish, the economic significance of which is growing. Since the late $19^{\text {th }}$ century the
Northern Sea Route (Northeast Passage) along the Russian northern seashore has been used as a transportation route. Being an area where the territorial boundaries between the Arctic states pass, its role in providing the national security through keeping up the military presence cannot be ignored. At the same time, it is a unique ecosystem, comprising the most extensive wilderness areas, rare reproduction places for animals, and northern fragile landscapes. Its continental areas still home the indigenous peoples who have managed to preserve their traditional and environmentally favorable lifestyles.

(C) Siberian Federal University. All rights reserved

* Corresponding author E-mail address: kafzem@yandex.ru 
As compared to other Arctic states, Russia has the longest coastline (about $50 \%$ (Report on the Arctic policy..., 2016) of the total length of $45390 \mathrm{~km}$ ) and claims to a larger extension of the continental shelf.

Historically, active explorations of the Arctic started back in the early $20^{\text {th }}$ century with the expeditions of local northern people in Russia and other Arctic states. However, earlier important events in the exploration of the Arctic are also known, the opening of Svalbard (Spitsbergen) by the Dutch explorer Barents in 1596 being one of them. The isle remained a "no man's land" up until 1920 when it was recognized a Norwegian territory under the Svalbard Treaty.

In the early $20^{\text {th }}$ century the five states directly bordering the Arctic ocean (Russia, USA, Canada, Denmark, and Norway) gradually initiated the territorial claims to the Arctic that were based on the sector principle. Canada was the first to claim its rights to the Arctic sector of the country up to the Northern Pole from its continental boundaries, when in 1909 it declared the isles and lands within the area its property. Soon afterwards, basing on several acts finalized by a special Royal Decree of 1926, it was Canada who confirmed the claims by extending its sovereign rights to these areas and establishing the permitting procedure for all the activities within its sector. In 1926 Russia fixed the alike claim in a special Soviet law (Timchenko, 1997). Unlike Canada and Russia, the USA, Norway and Denmark did not formally adopt special laws regarding the Arctic sectors. However, their laws on continental shelf, fisheries and economic zones covered their Arctic sectors up to the Northern Pole (Territorial Claims in the Arctic). Since that time the Arctic states have been accelerating their explorations and use of natural resources of the region. With the Law of the Sea (UNCLOS) entering into force in 1994, the sectorial principle for the territorial claims has become a disputed one. This is due to the fact that, according to the general rule of the Convention, the marine areas beyond 200 nautical miles (the outer limit of the continental shelf and exclusive economic zone) are supposed to be open for use by all the states. This event has catalyzed an active presence of the non-Arctic states in the Arctic Ocean for the moment, mostly with an aim of scientific research, mapping, and exploration of natural resources. Meanwhile, in accordance with the UNCLOS, the five Arctic states are filing claims to the extended continental shelf, that is, if proved, the certain Arctic states will be allowed to extend their jurisdiction to larger seabed areas (Territorial Claims in the Arctic). This territorial crossroad has environmental implications as well, as the fight for continental shelf jurisdictions is to a much extent determined by the interest in the development of natural resources, especially oil, gas, and fish.

Russia vests a lot of its national interest with the Arctic. It controls the largest exclusive economic zone in the Arctic and attaches a lot of importance to strengthening the control over this northern area that is currently substantiated by predominantly national security and potential oil extraction interests. According to the statistics, $80-90 \%$ of gas and $10-17 \%$ of oil come from the Russian Arctic, predominantly from the onshore oil and gas fields (Oil and Gas of the Russian Arctic...) with roughly $1,7 \%$ of the total Russian population living here (Bol'shunovskaia, Sentsov, 2016).

The country's military fleet with its nuclear weapons has had its base in the vicinity of the northern city of Murmansk since the 50s and it still remains an important military area. In 1954, the Soviet Union opened a nuclear testing ground at the New Land Island, where it actually performed nuclear tests up until 1990. In October 1969, there was a serious nuclear accident when radioactive gases vented after an underground 
test (Nuclear Explosions in the USSR...). Despite a lot of criticism addressed to such activities, the Head of the Russian Agency for Nuclear Energy stated in 2004 that the country is not going to close the testing ground. Yet, it is going to limit its use to non-nuclear experiments only in order to ensure the reliability and security of its nuclear weapons (New Land).

These economic and military activities in the Russian territory have increased the pressure on the fragile ecosystem of the Arctic and caused current dangerous problems of environmental pollution and endangered ever more natural lifesupporting systems of the indigenous people. Intentional use of the Arctic for oil and gas extractions, transportation, security, including the operation and maintenance of military fleet and bases, has further potential environmental dangers that, according to common international environmental concerns, cannot be overcome without environmental prevention and response measures.

The traditional environmental problems such as pollution are supplemented by a relatively new one, which is climate change. According to the data, the sea ice coverage in the Arctic ice decline has accelerated in the course of the last decades due to climate warming (Arctic Sea Ice Decline). This phenomenon is assessed in Russia from two perspectives. On the one hand, it will require certain efforts to reduce the emissions of greenhouse gases and to take the adaptation measures that will demand financial expenses. On the other hand, warming may facilitate further economic use of the Arctic. Environmental concerns force, inter alia, to work out adequate legal responses.

The first steps in this direction have been taken within political acts. In 2008, by Fundamentals of State Policy of the Russian Federation in the Arctic for the Period up until 2020 and Further Perspective, approved by the
President of the RF, the Northern areas were designated as the Arctic Zone of the Russian Federation (Osnovy gosudarstvennoi politiki Rossiiskoi Federatsii v Arktike...). The Zone comprises the administrative land territories of all RF regions along the Northern seashore, territorial sea, continental shelf, and the economic zone of the RF.

In 2013, the President of the RF approved the Strategy for the Development of the Arctic Zone of the Russian Federation and the National Security (the Arctic Strategy) that outlines the objectives and measures for the integrated social and economic development of the Arctic Zone (Strategiia razvitiia arkticheskoi zony Rossiskoi Federatsii...). Among the objectives and priorities of the state policy are further expansion of the resource base, including the development of energy resources and use of aquatic bio-resources and other strategic natural resources. They also encompass prioritizing the military security, climate change and environmental conditions monitoring development, science and technology development with due consideration of unique natural and climatic conditions. Relating to environmental protection it is generally declared to conserve the natural environment of the Arctic and to eliminate the ecological impacts of economic activities. The Strategy is being gradually implemented through adoption of certain legal acts. In 2014, the "Socio-Economic Development of the Arctic Zone" state programme sets a plan of measures to be fulfilled by 2025 (Ob utverzhdenii gosudarstvennoi programmy "Sotsial'noEkonomicheskoe razvitie Arkticheskoi zony...). It should be noticed that the Programme does not mention pure environmental aims and practical actions. Environmental concerns are implicitly integrated into such areas as the general raise in the population's life quality with an environment component as its integral part, the support of the indigenous peoples' traditional life-styles, and the 
support of science and technology. An emphasis is put on new areas, such as the development of the Northern Sea Route (NSR) as a national transportation route and the accelerated socioeconomic development of the so-called "key development zones". Taking into consideration the location of the traditional settlements, the latter is based on the understanding that due to severe natural conditions preference should be given only to the selected territories suitable for living, introducing advanced technological innovations and economic development in general. The Programme should be funded from the federal budget, although certain private investments within the framework of the public projects to be worked out are also presumed. The legislators prepare and intend to review a draft law "On Key Development Zones in the Arctic" in summer 2018 that would provide for the governmental support of the infrastructure formation (The Law on Key Development Zones...).

In 2015, in pursuance of the Arctic Strategy, the government set up the State Commission on the Arctic as a coordinating entity with the advisory powers on the issues stated in the Arctic Strategy (Ob utverzhdenii Polozheniia o gosudarstvennoi komissii po voprosam razvitiia Arktiki...).

The above strategic acts clearly show that the Russian Arctic is officially recognized as a separate region with its set boundaries. Specific regional measures should be taken to ensure its sustainable socio-economic development while preserving the unique Arctic. It may be also noticed that while attaching special attention to the socio-economic issues of the Arctic zone, environmental priorities are not clearly listed in the above strategic acts. They are even not clearly integrated into the socioeconomic development of the region's areas. Such approach allows for much discretion to the public power as to whether and how to address them in the context of a specific profile of the Arctic nature.

However, it would be fair to mention that the environmental protection priorities outlined in other general political acts may be equally extended to the Arctic. They comprise the climate change responses, including adaptation to changing climatic conditions and mitigation of anthropogenic impacts on climate system $(\mathrm{O}$ klimaticheskoi doktrine ...), monitoring of climate changes ( $\mathrm{Ob}$ utverzhdenii Strategii deiatel'nosti $\mathrm{v}$ sfere gidrometeorologii...), conservation of biological diversity and removal of past (stocked) environmental damage, recovery of wastes, reducing air pollution in cities (O Strategii ekologicheskoi bezopasnosti...). In 2012, to ensure sustainable development of the Russian Federation, the President of the RF approved "Fundamentals of the State Policy in the Field of Ecological Development for the Period up until 2030" (Fundamentals of the State Policy in the Field of Ecological Development...) that generally state that the country should follow the model of ecologically oriented socio-economic development. This implies that the economic growth should secure favorable natural conditions, biological diversity and natural resources conservation to meet the needs of the present and future generations, protection of the individuals' environmental rights, and strengthening the environmental rule of law. The act provides for an overall conceptual basis for modeling the socioeconomic development that would incorporate the aspects of environmental protection and extends to the Russian Arctic as well.

In contrast to regarding the Russian Arctic as a unique geographic and currently administrative region for working out and establishing the specific models of socio-economic development, a unified ecosystem approach to dealing with the ecological issues is lagging behind. Natural resources use, conservation of valuable 
ecological territories and objects, protection of the environment against pollution in the Arctic ecosystem are regulated in a fragmentary manner when they are legally addressed in numerous branch laws while touching upon several selected aspects relating to the Arctic only.

The latter concerns the establishment of the NSR legal regime and the actions to remove the past (stocked) environmental damage. The Federal Law "On Internal Sea Waters, Territorial Sea and Adjacent Zone" federal law (1998) (O vnutrennikh morskikh vodakh...) declares the NSR a historically originated national transportation route that is to be exploited in conformity with the international agreements and national legislation. Thus, the route has acquired a dual regime: remaining a national heritage and being located at least in part within the state boundaries, in addition to national legal requirements it is placed under the international agreements. In July 2012, the Code of Commercial Navigation (1999) (Kodeks Torgovogo Moreplavaniia...) was supplemented with an extensive new article specifically and in detail regulating the use of the NSR. In particular, it states that navigation there should comply with the Navigation Regulations in the Aquatic Area of the NSR approved by the Transportation Ministry in January 2013 (Pravila plavaniia v akvatorii Severnogo morskogo puti...). These Regulations as stated in the Law shall be aimed at ensuring the safety of sailing and also prevention, reducing and controlling the pollution of the sea by the vessels. Ships are required to obtain the sailing permits that will be issued on condition that the safety requirements and the requirements to ensure protection of the marine environment against the pollution from ships are complied with. Organization of sailing is vested with the NSR Administration, including permition and assistance in emergencies connected with the elimination of pollution from ships. Permits shall be issued on condition that an applicant provides with a proof in conformity with the international rules of insurance or another financial security paper, covering the liability for pollution or other damage. The Regulations also establish the requirements of having emergency equipment on board a vessel. Dumping of oil wastes into waters is prohibited.

Stocked environmental damage presents a specific challenge for the Russian Arctic. In 2010, after his visit to the Franz Josef Land Archipelago the Prime Minister Putin named it a gigantic landfill and called for its clean-up. Several expeditions for assessing the situation have been undertaken since that time and actual cleaning works were started. According to the data, the archipelago is one of the highly polluted hot points in the Arctic. It consists of 192 islands that have stocked 60000 tons of dangerous wastes, including oil wastes barrels and oil military equipment. The pollution there exceeds the permissible level by 6 times (Meeting with Participants in an Environmental Expedition...). The Prime Minister's visit catalyzed a series of government projects aimed to clean up the waste dumps along the Arctic seashore and at the islands (Detoxifying the Arctic...). Under the "Environmental Protection" governmental programme for the years 2012-2020, initially adopted by a governmental order on December 27, 2012 (Gosudarstvennaia programma "Okhrana okruzhaiushchei sredy...), the elimination of the stocked environmental damage at the Franz Josef Land Archipelago was included into priority environmental projects, and later within the new version of the Programme, approved by a governmental decree on April 15, 2014, the clean-up of the Franz Josef Land archipelago was reaffirmed. In 2009, the Franz Josef Land archipelago, the New Land archipelago and the adjacent marine areas were declared protected natural reserves and then, in 2011 - the "Russian 
Arctic" National Park (Natsional'nyi park "Russkaia Arktika"...) where no economic activities and natural resources development shall be permitted (Ob utverzhdenii Polozheniia o natsional'nom parke "Russkaia Arktika"...).

The Arctic clean-up challenge has to a great extent encouraged setting up of a firm legal base for the long-term actions in dealing with stocked environmental damage. In 2016, the Federal Law "On Environmental Protection" was amended with new chapter XIV.1 "Elimination of Stocked Environmental Damage" that provides for the inventory of the stocked environmental damage sites, the criteria being the location of uncontrolled industrial objects and waste disposal dumps within them, assessment of their negative environmental impact, their entry into the registry and vesting an obligation to arrange for works to eliminate the damage upon public authorities. At the moment there is an on-going discussion about who should be vested an obligation to finance and carry out the clean-up activities (Khludeneva, 2017). The Law “On Environmental Protection" does not clearly specify who should be nominated a responsible person for these activities in a situation when certain waste sites which were polluted in the past are the "non guilty" legal persons' property nowadays. Imposition of a clean-up obligation would be an overburden for them and may hold the economic development back. At the same time, the federal budget would hardly bear all expectedly high expenses. By the moment Article 80.2 of the Law declaratively states that such works should be arranged for by a specially nominated federal authority without defining the legal implementation mechanisms to be practiced in this case. This financial problem is not that topical for the Franz Josef Land Archipelago that has never been privatized and remains in the federal ownership. Therefore, the clean-up projects there have been carried out at the expense of the federal budget. Nonetheless, the issue is not settled, and the governmental legal decisions on financial implications of the clean-up of the past environmental damage may be expected.

The potential oil spills due to the development of explored oil and gas reserves within the Arctic Zone also present a growing environmental challenge for Russia. However, in practical terms it is currently rather a speculative problem than a real one. One may hardly speak about the risk of oil spills. There is only one offshore oil field (Prirazlomnoe) within the marine areas which is under development. This conforms to the best international environmental standards and practices (The Prirazlomnoe project...).

The minerals legislation that is applicable in this case is quite well developed and may be viewed as sufficient for the Arctic. The federal law on the Continental Shelf (1995, new version of 2 May 2015) requires that the mineral reserves within the continental shelf shall be developed under a government license. The license should prescribe environmental protection measures, including monitoring, the measures aimed to reduce environmental damage, prevent and eliminate oil spills and other emergencies, insurance conditions. In December 2012, the new provisions were added in response to the growing oil deposits exploration and development and arising risks of oil spills. In particular, it is required that the license should determine technical means to be used for removal of oil spills in ice conditions. Oil companies should establish an emergency preparedness system that should include emergency plans, availability of rescue teams and emergency warning system and should set up a reserve fund for oil spills removal. Mineral extraction projects as well as emergency plans for cases of oil spills are subject to a government ecological expertise (similar to EIA) and may be carried out only upon a positive assessment by the experts. The law was also amended with the provisions concerning 
such activities as construction and operation of pipelines, drilling works, and construction of artificial islands. In particular, the companies engaged in such works are obliged to prepare and get a state approval of plans for prevention and elimination of oil spills. Mineral exploration or exploitation activities are prohibited within specially protected areas. Drilling may be carried out upon state permits and should conform with environmental requirements.

In contrast to the established environment protection rules covering the Arctic region of Russia, although in a fragmentary way, there is still a gap in addressing climate change challenges. Under the Presidential Decree "On Reducing Greenhouse Gases Emission" Russia has assumed an obligation to reduce the emission by $75 \%$ by 2020 as compared with 1990 (O sokrashchenii obioma vybrosov parnikovykh gazov...). To meet this objective two principle legal mechanisms are activated: the first one is setting emission limitations for the sources of pollution and the second one is transition to alternative energy sources and raising of energy efficiency. For the moment, an emission concentration in the air is set only for one greenhouse gas out of the Kyoto list, the gas being nitrogen trifluoride oxide. Therefore, emissions of other greenhouse gases remain out of the administrative control (Ob utverzhdenii gigienicheskikh normativov GN 2.1.6.3492-17...). The situation may change as soon as in 2020, when, according to the 2014 amendments to the Law "On Environmental Protection" ( $\mathrm{O}$ vnesenii izmenenii v Federal nyi zakon $\mathrm{Ob}$ okhrane okruzhaiushchei sredy...), the requirement for the use of the best available technologies will be put into effect. The provision states that while introducing such technologies all emissions of pollutants shall be assessed (O poriadke opredeleniia tekhnologii...).

A more noticeable role in the context of mitigating climate change impacts is generally attached to raising energy efficiency and introducing alternative energy sources. This is addressed in the Federal law "On Energy Saving and Energy Efficiency Raising" (Ob energosberezhenii i povyshenii energeticheskoi effectivnosti...). The Energy Strategy of Russia (Ob energeticheskoi strategii...) provides for a direct governmental support for the nuclear energy development and encouraging the coal energy production ("clean coal" technology).

Adaptation to climate change that is especially important for the Russian Arctic lacks the legal regulation of the response actions. Except for a well-developed general legislation on emergencies ( $\mathrm{O}$ zashchite naseleniia $\mathrm{i}$ territorii ot chrezvychainykh situatsii...) and clear government policies, recognizing global climate change as one of the hazards to protection against emergencies (Ob utverzhdenii Osnov gosudarstvennoi politiki...), no clear legal acts deal with the issue.

In recognizing the integrity and vulnerability of the Arctic ecosystem, its value for the national security and considering it a natural resource reserve and at the same time a populated and economically developed area comprising the territories of traditional nature use by the indigenous people, the attempts are made to prepare a comprehensive draft law on the Arctic Zone are made (Lukin, 2016). This idea is widely discussed in scientific circles and in the government (Ministry of Economic Development drafts...). The governmental version of the draft act attaches a rapt attention to the issues of social and economic development, providing for the government support to the population, social benefits, tax releases, and encouragement of economic investments. Environmental protection is addressed without covering the specifics of the Arctic environmental challenges. The legal science points to the lack of "the legal mechanism of a real, not formal solution of nature protection 
issues in the Arctic Zone", the deficiencies of the EIA and ecological expertise, compensation of environmental damage, standard setting" (Khludeneva, 2015). Yet, according to the critics, it should be also noted that climate change response actions are entirely missing in the draft act.

Nonetheless, the adoption of a law on the Arctic seems justified. To avoid the framework model of the draft, it would be reasonable to single out the environmental block of issues of the general socio-economic development and to concentrate on drafting a separate codified and innovative law on environmental protection of the Arctic Zone. Similar to the Federal Law "On Protection of the Lake Baikal", the draft should be based on the ecosystem approach to regulating all nature-related activities in the Arctic.

This approach is justified by a generally recognized integrity of the Arctic ecosystem and its unique natural features and will make it possible to adapt the traditional legal mechanisms of environmental protection to the regional specifics. It seems feasible to use the existing mechanisms of territorial zoning, while providing for establishing special climate sensitive zones, introducing special regime and management of its coastal zone, updating of the environmental quality standards and emission limitations. The draft should address such hot issues like removal of stocked environmental damage, establish strict waste management rules, and provide for the involvement of best available technologies and best available practices in environmental protection, to regulate the response actions to oil spills and biodiversity conservation. It should be also focused on the study and use of the local and indigenous people's customs and traditions to support climate adaptation and resilience.

\section{References}

Arctic Sea Ice Declines. Available at: http://en.wikipedia.org (accessed 2 February 2018).

Arktika [The Arctic]. Available at: http://ru/wikipedia.org (accessed 25 January 2018).

Bol'sunovskaia, Iu., Sentsov, A. (2016). Human Potential as a Strategic Resource of the Russian Arctic Sustainable Development. Available at: earchive.tpu.ru (accessed 18 February 2018).

Detoxifying the Arctic - 10,600 Tons of Waste Removed from Franz Josef Land archipelago. Available at: www.syberiantimes.com (accessed 18 February 2018).

Gosudarstvennaia programma "Okhrana okruzhaiushchei sredy na 2012-2020 gody" [Governmental Programme "Environmental Protection for 2012-2020”]: adopted by the Governmental Order of December 27, 2012. Available at: http://www.consultant.ru (accessed 2 February 2018).

Ignatieva, I.A. (2017). Pravovoe obespechenie likvidatsii nakoplennogo vreda okruzhaiushchei srede [Legal Support for the Accumulated Environmental Damage], In Russian Law Journal, 2, 164-177.

Khludeneva, N.I. (2015). Perspektivy razvitia pravovoi okhrany arkticheskikh ecosistem [Perspectives in the Development of the Arctic Ecosystem Legal Protection], In Russian Law Journal, $11,114-122$.

Khludeneva, N. (2017). Effektivnost' regulirovaniia okhrany okruzhaiushchei sredy v Rossii: ot "konflikta tselei" k verkhovenstvu ekologicheskogo prava [Effectiveness of Environmental Protection Legal Regulation in Russia: from "Conflict of Goals" to Environmental Legal Order], In Russian Law Journal, 12, 141-150.

Kodeks Torgovogo Moreplavaniia [The Code of Commercial Navigation]: Federal Law from April 30, 1991 No. 81-FZ. Available at: http://www.consultant.ru (accessed 2 February 2018). 
Kolodkin, A.L., Gutsuliak, V.N., Bobrova, Iu.V. (2007). Mirovoi okean: mezhdunarodno-provovoi rezhim. Osnovnye problemy [The World Ocean: the International Legal Regime. Key Problems]. Moscow, Statut, 637 p.

Lukin, Iu. (2016). Rossiiskaia Arktika ili Arkticheskaia zona [The Russian Arctic or the Arctic Zone], In Arctic and North, 23. Available at: http://www.narfu.ru (accessed 18 February 2018).

Meeting with Participants in an Environmental Expedition to Franz Josef Land Archipelago. Available at: www.en.kremlin.ru (accessed 18 February 2018).

Ministry of Economic Development Drafts the Arctic Zone Development Project. Available at: https://arctic.ru/infrastructure/20171110/686564.html (accessed 23 February 2018).

Natsional'nyi park "Russkaia Arktika" [The Russian Arctic National Park]. Available at: www. rus-arc.ru (accessed 18 February 2018).

Neft' i gaz rossiiskoi Arktiki: istoriia osvoeniia v XX veke, resursy, strategiia na XX vek [Oil and Gas of the Russian Arctic: the History of Development in the $20^{\text {th }}$ Century, Resources and Strategy for the $21^{\text {st }}$ Century], In SCIENCE First Hand, August 30, 2016. Russian Arctic, 41. Available at: www. scfh.ru (accessed 20 January 2018).

New Land. Available at: http://ru.wikipedia.org (accessed 2 February 2018).

Nuclear Explosions in the USSR: the North Test Site Reference Material. Available at: www-ns. iaea.org (accessed 2 February 2018).

O klimaticheskoi doctrine Rossiiskoii Federatsii [On the Climate Doctrine of the Russian Federation]: Presidential Order of December 17, 2009, No. 861-rp. Available at: http://www.consultant. ru (accessed 2 February 2018).

O poriadke opredeleniia tekhnologii v kachestve nailuchshei dostupnoi tekhnologii, a takzhe razrabotki, aktualizatsii i opublikovanii informatsionno-tekhnicheskikh spravochnikov po nailuchshim dostupnym tekhnologiiam [On the Procedure of Determining a Technology as a Best Available One, and Also on Development, Updating and Publication of the Reference Books on the Best Available Technologies]: Governmental Decree No. 1458 of December 23, 2014. Available at: http://www. consultant.ru (accessed 2 February 2018).

O sokrashchenii obioma vybrosov parnikovykh gazov [On Reducing the Emissions of Greenhouse Gases]: the Decree of the President of the Russian Federation No. 504-r from April 2, 2014. Available at: http://www.consultant.ru (accessed 2 February 2018).

O Strategii ekologicheskoi bezopasnosti Rossiskoi Federatsii na period do 2025 goda [On the Strategy of Ecological Security of the Russian Federation up until 2025]: the Presidential Decree No. 176 of April 19, 2017. Available at: http://www.consultant.ru (accessed 2 February 2018).

O sukhoputnykh territoriiakh Arkticheskoi zony Rossiskoi Federatsii [On Surface Areas of the Arctic Zone of the Russian Federation]: the Presidential Decree No. 269 of May 2, 2014. Available at: http://www.consultant.ru (accessed 2 February 2018).

$O$ vnesenii izmenenii $v$ Federal'nyi zakon ob okhrane okruzhaiushchei sredy $i$ otdel'nye zakonodatel nye akty Rossiiskoi Federatsii [On Amending the Federal Law on Environmental Protection and the Selected Legislative Acts of the Russian Federation]: Federal Law No. 219-FZ of July 21, 2014. Available at: http://www.consultant.ru (accessed 2 February 2018).

O vnutrennikh morskikh vodakh, territorial nom more i prilezhashchei zone Rossiiskoi Federatsii [On Internal Sea Waters, Territorial Sea and Adjacent Zone]: Federal Law No. 155-FZ from July 31, 1998. Available at: http://www.consultant.ru (accessed 2 February 2018).

$$
-949-
$$


$O$ zashchite naseleniia $i$ territorii ot chrezvychainykh situatsii prirodnogo i tekhnogennogo kharaktera [On Protection of Population and Territories Against Natural and Man-Made Emergencies]: Federal Law No. 68-FZ of December 21, 1994. Available at: http://www.consultant.ru (accessed 2 February 2018).

Ob energeticheskoi strategii Rossiiskoi Federatsii na period do 2030 goda [On Energy Strategy of the Russian Federation up until 2030]: Governmental Order № 1715-r of November 13, 2009. Available at: http://www.consultant.ru (accessed 2 February 2018).

Ob energosberezhenii i povyshenii energeticheskoi effektivnosti [On Energy Saving and Raising the Energy Efficiency]: Federal Law No. 261-FZ of November 23, 2009. Available at: http://www. consultant.ru (accessed 2 February 2018).

Ob utverzhdenii gigienicheskikh normativov GN 2.1.6.3492-17 "Predel'no dopustimye kontsentratsii (PDK) zagriazniaiushchikh veshchestv v atmosfernom vozdukhe gorodskikh i sel skikh poselenii» [On Approving the Hygienic Regulations GN 2.1.6.3492-17 "Maximum Permissible Concentration of Pollutants in the Air of Urban and Rural Settlements"]. Available at: http://www. consultant.ru (accessed 2 February 2018).

Ob utverzhdenii gosudarstvennoi programmy "Sotsial no-Ekonomicheskoe razvitie Arkticheskoi zony Rossiiskoi Federatsii" [On Approving the State Programme "Socio-Economic Development of the Arctic Zone of the Russian Federation"']: Governmental Decree No. 366 of April 21, 2014. Available at: http://www.consultant.ru (accessed 2 February 2018).

Ob utverzhdenii osnov gosudarstvennoi politiki $v$ oblasti zashchity naseleniia $i$ territorii ot chrezvychainykh situatsii na period do 2030 goda [On Approving the Fundamentals of the Government Policy in the field of Protection of Population and Territories Against Emergencies up until 2030]: Decree of the President of the Russian Federation No. 12 of January 11, 2018. Available at: http://www.consultant.ru (accessed 2 February 2018).

Ob utverzhdenii Polozheniia o gosudarstvennoi komissii po voprosam razvitiia Arktiki [On Approving the Regulations for the State Commission on the Arctic Development]: Governmental Decree No. 228 of March 13, 2015. Available at: http://www.consultant.ru (accessed 2 February 2018).

Ob utverzhdenii Polozheniia o natsional nom parke "Russkaia Arktika" [On Approving the Regulations for the "Russian Arctic" National Park]: Order of the Ministry of Natural Resources and Ecology No. 806 of October 3, 2011. Available at: http://www.consultant.ru (accessed 2 February 2018).

Ob utverzhdenii Strategii deiatel nosti v sfere gidrometeorologii i smezhnykh s nei oblastiakh na period do 2030 goda [On Approving the Strategy in Hydrometeorology and Adjacent Areas up until 2030]: Governmental Order No. 1458-r of September 3, 2010. Available at: http://www.consultant.ru (accessed 2 February 2018).

Osnovy gosudarstvennoi politiki Rossiiskoi Federatsii v Arktike na period do 2020 goda $i$ dal neishuiu perspektivu [Fundamentals of the State Policy in the Arctic for the Period up until 2020 and in the Further Perspective]: Approved by the President of the Russian Federation No. Pr-1969 of September 18, 2008. Available at: http://www.consultant.ru (accessed 2 February 2018).

Osnovy gosudarstvennoi politiki v oblasti ekologicheskogo razvitiia Rossiiskoi Federatsii na period do 2030 goda [Fundamentals of the State Policy in the Field of Ecological Development of the Russian Federation up until 2030]: Approved on April 30, 2012. Available at: http://www.consultant. ru (accessed 2 February 2018). 
Pravila plavaniia $v$ akvatorii Severnogo morskogo puti [Regulations for Navigation in the Aquatic Area of the Northern Sea Route]: Approved by the Decree of the Transportation Ministry of the Russian Federation No. 7 of January 17, 2013. Available at: http://www.consultant.ru (accessed 2 February 2018).

Report on the Arctic Policy. International Security Advisory Board. September 2016. United States Department of State. Available at: www.state.gov (accessed 18 February 2018).

Strategiia razvitiia Arkticheskoi zony Rossiskoi Federatsii $i$ obespechenie natsional noi bezopastnosti na period do 2020 goda i dal'neishuiu perspektivu [Strategy for the Development of the Arctic Zone of the Russian Federation and Providing the National Security up until 2020 and in the Further Perspective]: Approved by the President of the Russian Federation on February 8, 2013. Available at: http://www.consultant.ru (accessed 2 February 2018).

Svalbard Treaty. Available at: www.wikipedia.org (accessed 2 February 2018).

Territorial Claims in the Arctic. Available at: www.wikipedia.org (accessed 15 January 2018).

The Law on Key Development Zones shall be Discussed in Summer. Available at: www.severpress.ru (accessed 2 February 2018).

The Prirazlomnoe Project - GSC Gazprom Neft. Available at: www.gazprom-neft.com (accessed 1 February 2018).

Timchenko, L. (1997). The Russian Arctic Sectoral Concept: Past and Present, In Arctic, 50, 2935. Available at: pubs.aina.ucalgary.ca (accessed 18 February 2018).

\title{
Российская Арктика: экологические вызовы и правовые ответы
}

\author{
И.О. Краснова, В.Н. Власенко \\ Российский государственный университет правосудия \\ Россия, 117418, Москва, ул. Новочеремушкинская, 69
}

В статье представлен анализ экологического законодательства применительно к уникальной экосистеме Арктики. Авторы приходят к выводу, что законодательство носит фрагментарный характер с пробелами и недостатками, включая, в частности, отсутствие правового регулирования в области изменений климата. В статье обосновано, что иелостность экосистемы Арктики, ее природная уязвимость, а также перспективы растущего экономического освоения природных ресурсов определяют необходимость подготовки и принятия комплексного законодательного акта об охране окружающей среды Арктической зоны Российской Федерации, в содержание которого войдут вопросы нормирования воздействий, внедрения наилучших доступных технологий, предупреждения и устранения последствий разливов нефти, сохранения биологического разнообразия, ликвидации накопленного вреда окружающей среде, комплексного управления береговой зоной и меры адаптации к изменениям климата.

Ключевые слова: стратегия развития Арктической зоны, накопленный вред окружающей среде, нормативы воздействий, меры реагирования на разливы нефти, адаптация к изменениям климата, экологическое развитие.

Научная специальность: 12.00.00 - юридические науки. 